Check for updates

New York, USA

Cite this as: BMJ2020;370:m3072 http://dx.doi.org/10.1136/bmj.m3072 Published: 03 August 2020

\section{Covid-19: US needs a national plan to fight rising infections, experts}

\section{say}

\author{
Janice Hopkins Tanne
}

Three scientific organisations have proposed plans for the US to gain control of the pandemic as a leading Democrat declared that it was a "public health catastrophe" with more infections and deaths than any other country,

South Carolina Democrat James Clyburn, chairman of the House of Representatives Select Subcommittee on the Coronavirus Crisis, said at a committee hearing on 31 July that President Donald Trump had downplayed the urgency of the pandemic and deferred responsibility to individual states. Clyburn said that the US urgently needed a national plan to contain the virus.

An article in Vanity Fair reported that the president's son-in-law, Jared Kushner, had a secret project to set up a national system of oversight and coordination to provide supplies, test kits, and establish a surveillance programme. It claimed that the plan was dropped because the virus hit Democrat states hardest, rather than Trump's Republican base.

During the House committee hearings, ranking Republican Steve Scalise of Louisiana said Trump had already created a national plan and held up a pile of documents. Maryland Democrat Jamie Raskin countered, "A stack of paper is not a plan. Blaming China is not a plan." Raskin said Trump's "lethal incompetence" had led to 54 million people becoming unemployed, a one third drop in the gross domestic product, and close to five million infections.

As of 2 August, the US had at least 4657625 cases and 154793 deaths. ${ }^{2}$ In the past two weeks, cases have increased in 23 states and in the territory of Puerto Rico. ${ }^{3}$

At the hearing, Anthony Fauci, director of the National Institute of Allergy and Infectious Diseases, said that while other countries had closed down their economies "about 95\%" to control the virus, the US had closed down only about $50 \%$ when there were around 20000 cases a day. Reopening led to as many as 70 ooo cases a day. The increase in cases was real, not because of increased testing, he said, and rapid, point-of care tests were needed.

Admiral Brett Giroir, assistant secretary of health and human services and the "testing czar," said that more than $40 \%$ of tests had taken more than three days, which made contact tracing difficult. He said the delay was because of high demand.

Robert Redfield, director of the Centers for Disease Control and Prevention, Fauci, and Giroir all repeated that the public should wear masks, practise social distancing, avoid indoor crowds (such as in bars), and frequently wash their hands. Investment in public health, neglected for 50 years, should be increased.

National plans to control covid-10 were proposed by the Association of American Medical Colleges, the Center for Health Security at Johns Hopkins University, and the Rockefeller Foundation.

"Testing is the only way out of our present disaster," the Rockefeller Foundation asserted in its report, based on consultation with government, business, and educational experts. The foundation said it would invest \$5om (€38m; €43m) in addition to earlier contributions. It called for the federal government to invest $\$ 75 \mathrm{bn}$ for testing. 4

Testing, contact tracing, improved data collection and infrastructure, and communication of "consistent, fact based" information are needed, the report said. It called for the US to carry out 30 million tests a week by October. A fast, point-of-care test at no cost to the individual is needed and should be widely available, particularly for essential workers and those on low incomes and in minority communities.

While diagnostic testing is important, widespread screening is needed before the flu season begins in October, the report said. Screening can identify people who are asymptomatic so they can isolate and prevent spread, making it easier for schools and universities to reopen and for businesses to operate safely.

The Association of American Medical Colleges presented steps to reset the nation's approach to the pandemic. ${ }^{5}$ Among other things, it called for correcting supply and drug shortages and increasing availability and accessibility of tests to 2.3 million per day. It also said that national standards were needed for face coverings along with criteria for lockdowns and reopenings.

The Center for Health Security at Johns Hopkins University proposed a 10 point plan ${ }^{6}$ which included encouraging or requiring face covering, physical distancing, hand hygiene, and avoidance of indoor crowds and closing activities in areas where infections are increasing, and stay-at-home orders when in crisis. 
2 Covid-19 dashboard by the Center for Systems Science and Engineering at Johns Hopkins University. https://gisanddata.maps.arcgis.com/apps/opsdashboard/index.html\#/bda7594740fd40299423467b48e9ecf6.

3 Coronavirus in the US. Latest map and case count. New York Times. 2 August 2020. www.nytimes.com/interactive/2020/us/coronavirus-us-cases.html.

4 Rockefeller Foundation. National covid-19 testing and tracing action plan: time to redouble our efforts on covid-19 testing. 16 July 2020 . www.rockefellerfoundation.org/national-covid-19-testing-andtracing-action-plan.

5 Association of American Medical Colleges. The way forward on covid-19: a roadmap to reset the nation's approach to the pandemic. 29 July 2020 . www.aamc.org/covidroadmap/roadmap.

6 Center for Health Security, Johns Hopkins Bloomberg School of Public Health. Resetting our response: changes needed in the US approach to covid-19. 29 July 2020 . www.centerforhealthsecurity.org/news/center-news/2020-07-29-resetting-our-response-report.html. 